\title{
1998 SURVEY SHOWS CAMELLIA FLOWER BLIGHT IS WIDESPREAD IN NEW ZEALAND
}

\author{
C.H. TAYLOR, P.G. LONG and R.E. BRADSHAW \\ Institute of Natural Resources, Massey University, \\ P.O. Box 11-222, Palmerston North
}

\begin{abstract}
The fungus Ciborinia camelliae causes camellia flower blight and is considered the most serious disease of the genus Camellia. The disease spread from Japan to the USA in 1938 and was found in Wellington, New Zealand in 1993. Surveys in 1997 found that the disease was widely distributed in the western, central and lower North Island. A survey of New Zealand in 1998 found that the disease had not spread significantly in the North Island, except for an isolated outbreak in Auckland which was almost certainly from transfer of infected planting material or contaminated soil. In the South Island, the disease was found in Picton, Nelson, Golden Bay, Blenheim, Kaiapoi and Christchurch. It appears to have been there for at least three years.

Keywords: ascospores, Camellia spp., Ciborinia camelliae, distribution, sclerotia.
\end{abstract}

\section{INTRODUCTION}

Camellias (Family Theaceae) are one of the three most popular ornamental flowering tree groups (along with roses and rhododendrons) (Hagiya 1997), and are widely grown in New Zealand, Australia, the USA and Europe. The International Camellia Register (Savige 1993) records 267 species of the genus, all originating in greater Asia.

The most serious disease of camellias, camellia flower blight, is caused by Ciborinia camelliae Kohn, an ascomycete fungus of the Sclerotiniaceae. This fungus is a specialist pathogen, attacking only Camellia species and infecting only the flowers.

Infection occurs in early spring, when apothecia of the pathogen release ascospores. These cause small, brown lesions on the petals. The lesions enlarge and coalesce until entire flowers turn brown and fall from the plant. A characteristic sign of the disease is the grey or white felty mycelium around the base of petals when the bracts/sepals are removed. Sclerotia form in the petal tissue of the petal bases, and they then lie dormant in the soil over summer, autumn and winter, until they germinate in early spring.

Spread of camellia flower blight was discussed by Taylor and Long (1998). There is now a confirmed report of the disease in the UK (R. Cross pers. comm.), an unconfirmed report of the disease in Germany (Klaus Peper 1999 www.kamelien.de) and it is possibly in other European countries.

Following identification of camellia flower blight in Wellington (Stewart and Neilson 1993) and Waikanae and Wanganui (Neallet al. 1998), a 1997 survey showed the disease to be widespread in the lower, central and western North Island (Taylor and Long 1998). The main mode of disease spread appeared to be by windborne ascospores, with viable spores able to be blown at least $20 \mathrm{~km}$ (Taylor 1999). This indicated that the disease would continue to spread northward in the North Island and that it was possible for inoculum to be blown across Cook Strait to the South Island.

The present paper reports on the results of a survey undertaken in both the North and South Islands in the 1998-blight season (spring/early summer). Aspects of the pathogen's successful establishment in urban areas are discussed. 


\section{METHODS}

The survey was carried out in October and November 1998. It covered the South Island and much of the North Island south of Auckland using the methods described by Taylor and Long (1998).

The number of camellia plants examined in each city or town varied depending upon size of the locality and availability of camellias. Sufficient plants were examined in order to determine whether the disease was present or absent in the area. The disease distribution is often patchy (C. Hill, pers. comm.) and based on our 1997 survey experience, the 1998 survey method was modified so that larger towns and cities were each sampled from four quarters (north, south, east and west). This strategy increased the chances of discovering the disease, especially if it were only present in small amounts in a restricted area. The approach also allowed the local distribution of the disease to be evaluated.

Positive identification of camellia flower blight was made by the presence of sclerotia as signs of the pathogen in flower petals. In all cases where the disease was identified, or suspected, samples were taken back to the laboratory and held under suitable conditions for sclerotial formation. Alford (1961) and Alford et al. (1961) made positive identifications only if they found apothecia or sclerotia of the pathogen, but the sclerotia alone were considered sufficiently distinctive to be used for a positive identification in this study. Apothecia are frequently difficult to find in garden undergrowth and because the inoculum is windborne, apothecia may not be present at an infection site.

\section{RESULTS}

Camellia flower blight was found at seven new sites in the North Island and these, along with pre-1998 infection sites, are shown in Fig. 1. The 1998 survey results suggest that the disease has spread further round Mt Taranaki to Opunake and Okato. It was also found in Bulls, Woodville, Taihape and Taupo with an isolated outbreak

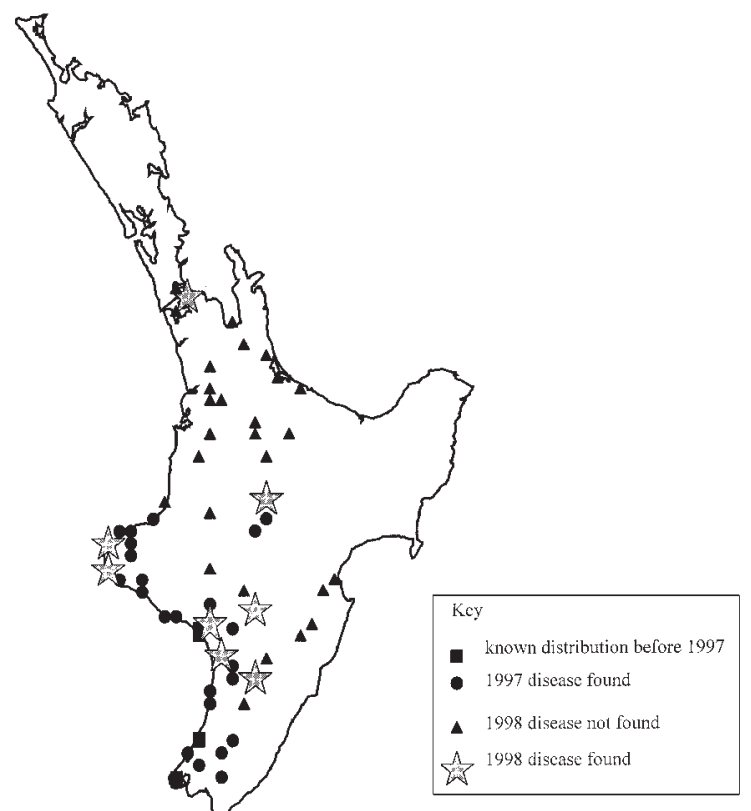

FIGURE 1: Distribution of C. camelliae in the North Island in 1998. 
detected in Mt Eden, Auckland. The disease was not found in the Hawkes Bay, or in the areas of Taumaranui, Te Kuiti, Hamilton, Tauranga, Rotorua or Tokoroa. Areas north of North Shore City/Waitakere City and Gisborne were not surveyed.

Camellia flower blight was found to be widespread in the northern half of the South Island (Fig. 2). It was present in Picton, Blenheim, Nelson, Stoke, Richmond, Motueka and many sites in Golden Bay and was found in seven suburbs in Christchurch (Templeton, Monavale, Sumner, Redcliffs, Heathcote, Fendalton and Bryndwyr). A single infected flower was found at Kaiapoi. The disease was not found anywhere else in the South Island.

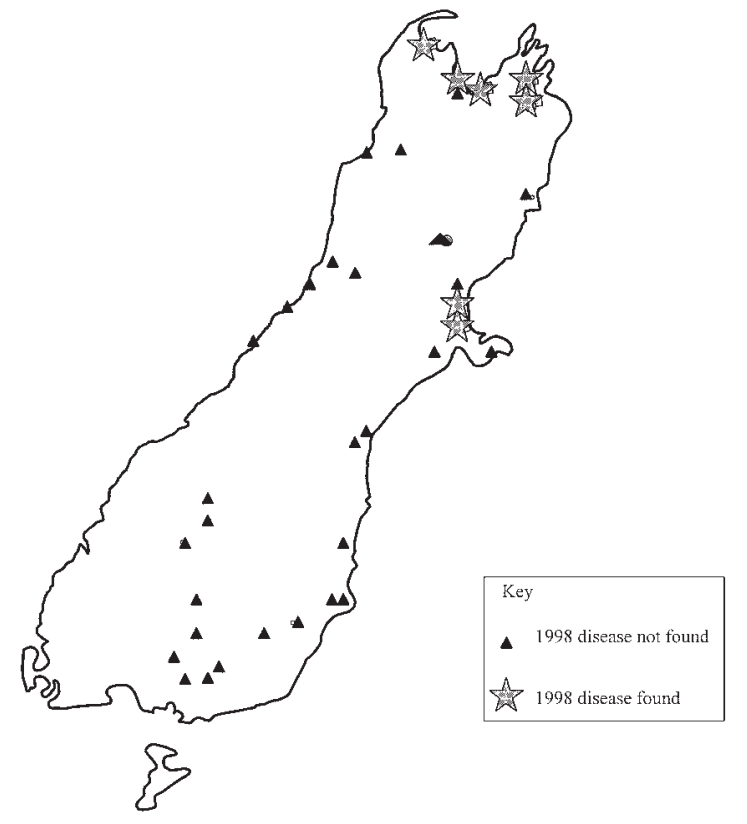

\section{FIGURE 2: Distribution of C. camelliae in the South Island in 1998.}

Many garden centres and nurseries were visited during the survey and several were found to have infected plants. These outlets were in regions where the camellia blight appeared to have been established for one or more years and where a large amount of inoculum might be expected in the air. No diseased plants were found at outlets in areas free of the disease.

\section{DISCUSSION}

These camellia flower blight surveys were limited by time and money and a thorough search was not possible in Christchurch and Auckland where the disease may be present in suburbs other than those in which it was found. A negative result from a site does not necessarily indicate that the disease was not present in an area, as not all flowers on all plants could be examined. However, the close proximity of infected locations and the large areas where the disease was not found give confidence that the overall pattern of distribution described from our surveys is correct.

Camellia flower blight is now present in both the North and South Islands (Figs. 1 and 2) and is far more widely distributed than thought prior to these surveys. It is widespread in the lower, central and western North Island, in the northern part of the South Island, and in Christchurch. In the North Island, the disease front appears to run 
from Urenui in the north-west, through Taupo to Woodville in the southeast. Few infected plants or flowers were found at this front, and none were located north of it (except Auckland). In the northern South Island, the disease front is delineated by mountain ranges to the south of Golden Bay/Nelson/Blenheim (except for Christchurch and Kaiapoi).

The isolated outbreaks of camellia flower blight in Auckland and Christchurch indicate that the disease has probably been transported/imported into these areas on diseased material rather than as windborne ascospores. In Mt Eden, Auckland, the disease incidence was low, suggesting a recent introduction event (possibly 1998 was the second year) whilst the distribution and high levels of disease found in Christchurch suburbs indicates that the introduction event(s) occurred at least three years ago. The disease was well established and widespread in Golden Bay/Nelson/Blenheim, and it was not possible to determine whether the pathogen had been windborne across the Cook Strait or had been introduced accidentally from the Wellington region. Picton is closer to Wellington than Golden Bay and Nelson but disease incidence there was low. This suggests the disease was probably introduced to the northern South Island on planting material taken to the Golden Bay and Nelson areas. Whether it then spread to Picton or whether the Picton infestation was due to windborne ascspores from Wellington is open to debate.

The widespread occurrence of camellia flower blight would indicate that the main method of spread has been through windborne ascospores, supplemented in part by the transfer of infected plant material/contaminated soil to disease-free sites. No other dispersal method could account for its current widespread distribution. In the South Island, settlements are fewer and more widely spaced, farm size is larger and there are extensive tracts of native vegetation. Thus, it is likely that host plants occur infrequently, and windborne ascospores may not be as important in its spread as is the case in North Island locations.

Camellia flower blight is a "community disease" (Zummo and Plakidas 1959) because camellias in urban areas are particularly vulnerable. Once established, the management and chemical control options individual gardeners undertake are only as effective as the measures being undertaken by the rest of the community. Camellias are widely planted in New Zealand, and camellia flower blight has become a significant problem facing camellia enthusiasts and exporters.

Very little is known about $C$. camelliae. We are currently developing molecular tools that will be used (in addition to identification by symptoms) to confirm Koch's postulates for the pathogen. We are also studying growth of the fungus within camellia twigs and will assess camellia varieties for relative susceptibility to the disease.

\section{REFERENCES}

Alford, D.M., 1961. Studies on Camellia Flower Blight. MSc, Louisiana State University, Baton Rouge, Louisiana, USA. Unpublished thesis.

Alford, D. M., Sinclair, J. B. and Pirone, T. P., 1961. Spread and distribution of camellia flower blight in Louisiana. Plant Disease Reporter 45: 856-857.

Hagiya, K., 1997. Bright future of camellias by hybridizing distant relatives. N.Z. Camellia Bulletin 127: 2-9.

Neall, V. E., Stewart, T. M., Bieleski, R. and Cooper, K., 1998. Camellia blight causing concern. Commercial Hort., January: 23-24.

Savige, T. J., 1993. The International Camellia Register. T. J. Savige, (Ed). The International Camellia Society, Sydney.

Stewart, T. M. and Neilson, H., 1993. Flower blight, a new disease of camellias in New Zealand. N.Z. Camellia Bulletin 116: 29-33.

Taylor, C. H., 1999: Studies of camellia flower blight (Ciborinia camelliae) in New Zealand. MAppSc, Massey University, Palmerston North. Unpublished thesis.

Taylor, C. H. and Long, P. G., 1998. Camellia flower blight in New Zealand.Proc. $51^{\text {st }}$ N. Z. Plant Prot. Conf:: 134-137.

Zummo, N. and Plakidas, A. G., 1959. Petal blight is a community problem.American Camellia Yearbook 1959: 114-116. 